\title{
Investigation into the hypogonadism of the obese mouse (genotype ob/ob)
}

\author{
R. A. L. Batt*, Deborah M. Everard†, Glenda Gilliesł, M. Wilkinson§, \\ Catherine A. Wilson $†$ and T. A. Yeo
}

${ }^{*}$ Department of Anatomy, Royal Veterinary College, London NWI OTU; †Department of Obstetrics \& Gynaecology, St George's Hospital Medical School, London SW17 OQT;

$\ddagger$ Pituitary Hormone Laboratory and $₫$ Department of Endocrinology, St Bartholomew's Hospital, London EC1 7BE; and §Department of Physiology, The Royal Free Hospital School

of Medicine, London NW3, U.K.

\begin{abstract}
Summary. Features of the reproductive axis in the genetically hypogonadal, obese mouse (genotype, ob/ob) were examined at 5-8 months of age and compared with those of wild-type litter mates. Hypothalamic concentrations of dopamine and 5-hydroxytryptamine were normal. Those of 5-hydroxyindoleacetic acid, noradrenaline and LH-RH were raised. LH-RH was biologically active. Pituitary concentration of $\mathrm{LH}$ was normal, but that of FSH was raised. Serum concentrations of LH and FSH, compared with those of wild-type animals, were normal and low, respectively. Gonad and accessory sex organ weights were reduced. These findings suggest that the release of FSH but not $\mathrm{LH}$ is defective in the ob/ob mouse.

Preliminary in-vitro experiments indicated that the pituitary gland responded normally or even supernormally towards LH-RH in its release of LH. The defect in the reproductive axis of the obese mouse may be due to inadequate release of LH-RH although an insensitivity of the pituitary gland towards LH-RH in its release of FSH cannot be excluded.
\end{abstract}

\section{Introduction}

The obese mouse (genotype, ob/ob) is characterized by numerous pathological features. As well as hyperphagic obesity, these include hypothermia and infertility associated with reduced gonadal and accessory organ weights (York, Bray \& Yukimura, 1978). The infertility is progressive. Initially, $20 \%$ of the male mice are fertile but this is transient (Lane, 1959). Before puberty the ovaries of obese and wild-type mice are indistinguishable, then a gradual involution ensues, the ovary of the obese mouse becoming unrecognizable (Jones \& Harrison, 1958; Batt, 1974). Vaginal opening is delayed by approximately 1 week and ovulation never occurs, reflecting low concentrations of circulating gonadal steroids as well as of gonadotrophins. These hormones have not been assayed in the female obese mouse although Swerdloff, Batt \& Bray (1976) have reported reduced plasma values of follicle-stimulating hormone (FSH) and testosterone in the male obese mouse. The impaired gametogenesis is responsive to exogenous gonadotrophins in females and males (Hummel, 1957; Jones \& Harrison, 1958). Responsiveness of the uterus to exogenous oestrogen is also similar to that of wild-type mice (Drasher, Dickie \&

$\S$ Present address: Department of Physiology \& Biophysics, Dalhousie University, Halifax B3H 4H7, Canada. 
Lane, 1955). Obesity and sterility are associated in other genetically determined syndromes of rodents (Bray \& York, 1979) but limiting the body weight by reduced food intake does not result in ovulation or oestrogen secretion in the obese mouse (Batt, 1974). By contrast, infusion of a hypothalamic extract into the region of the median eminence resulted in cornified cells appearing in the vaginal smear (Batt, 1972), confirming that endogenous gonadotrophins in the obese mouse are biologically active (Runner, 1952).

It therefore seems likely that the hypogonadism of the obese mouse is due to a defect at the hypothalamic and/or pituitary level, with a reduction in the synthesis or release of one or both gonadotrophins. This in turn may be due to an abnormal response of the hypothalamus or pituitary gland toward feedback effects of the gonadal hormones. Swerdloff et al. (1978) have examined the in-vivo response to luteinizing hormone-releasing hormone (LH-RH), Nemeroff, Bissette \& Kizer (1978) the LH-RH hypothalamic concentration and Lordon \& Oltmans (1977) neurotransmitter concentrations in the hypothalamus. In our attempt to specify the defect in the reproductive axis we have repeated some of the previous work and extended it to include measurements on the female obese mouse and, in both sexes, on the in-vitro release of LH concentrations of hypothalamic LH-RH (bioassay), hypothalamic 5-hydroxytryptamine and its precursor 5-hydroxyindoleacetic acid.

\section{Materials and Methods}

Animals for experiment were bred in the Animal House at the Royal Veterinary College, using stock derived from the similar Birmingham and Edinburgh colonies of non-inbred strains. The mice were kept in polypropylene boxes on sawdust (air temperature, $21-27^{\circ} \mathrm{C}$ ) in controlled lighting (12 h light (06:00-18:00 h)/24 h). Water and pelleted food (Diet 86, Dixons, Ware, Herts, U.K.) were provided ad libitum.

\section{Hypothalamic amines}

Animals were allotted to groups of 6-8 at 5-6 months of age according to obesity, sex and, for the wild-type mice, the stage in the oestrous cycle (Table 1). They were weighed and decapitated and their hypothalami dissected, strictly according to the method of Glowinski \& Iversen (1966). The hypothalami were weighed and stored at $-20^{\circ} \mathrm{C}$.

The extract from each hypothalamus was assayed fluorometrically for noradrenaline, dopamine, 5-hydroxytryptamine and 5-hydroxyindoleacetic acid. The 5-hydroxytryptamine and 5-hydroxyindoleacetic acid were extracted and measured by the method of Curzon \& Green (1970). The catecholamines were extracted according to the method of Welsch \& Welsch (1969) and measured by the method of Shellenberger \& Gordon (1971). The recoveries were noted by measuring internal standards in the presence of tissue and the yields were $105 \%$ for 5-hydroxytryptamine, $76 \%$ for 5 -hydroxyindoleacetic acid, $78 \%$ for noradrenaline and $74 \%$ for dopamine. Results were not corrected for recovery. The intra- and inter-assay coefficients of variance were 6.0 and $10.2 \%, 4.3$ and $17.7 \%, 3.6$ and $17.2 \%$ and 10.1 and $23.3 \%$, respectively.

\section{Hypothalamic $L H-R H$}

After decapitation, hypothalami from male obese mice and their wild-type litter mates, aged 5-6 months $(\mathrm{N}=8$ in each group), and 13 months $(\mathrm{N}=7$ in each group), were weighed and stored $\left(-20^{\circ} \mathrm{C}\right)$. They were subsequently thawed, homogenized in $1 \mathrm{~N}-\mathrm{HCl}$, centrifuged and the supernatant assayed for immunoreactive LH-RH (Mortimer et al., 1976). Hypothalami from 8 -month-old female obese and wild-type mice ( $\mathrm{N}=9$ in each group) were similarly extracted 
after removal and assayed for immunoreactivity and bioactivity of LH-RH. Biological activity of LH-RH was assessed using isolated perfused anterior pituitary cells (Yeo et al., 1977; Gillies \& Lowry, 1978). Briefly, the cells of the anterior pituitary glands of female Wistar rats were dispersed by mechanical agitation in Earles Balanced Salt Solution (EBSS) (Gibco Bio-cult Ltd, Paisley, Scotland) containing trypsin $(0.25 \% \mathrm{w} / \mathrm{v})$. The isolated cells were mixed with pre-swollen BioGel P2 (200-400 mesh), packed into a 2-ml plastic syringe and perfused $(0 \cdot 5$ $\mathrm{ml} / \mathrm{min}$ ) with EBSS containing $0.25 \%$ bovine serum albumin (Armour, Eastbourne, U.K.). Eluate was collected as 2-min fractions and assayed for LH (kits supplied by Dr A. F. Parlow and the NIAMDD, U.S.A.). The cell column was stimulated every $10 \mathrm{~min}$ with 1 -min pulses of synthetic LH-RH (Farbwerke Hoechst Ltd, Frankfurt (M)-80) or dilutions of neutralized extract.

\section{Pituitary and serum $L H$ and FSH}

LH was assayed in the same animals used to measure hypothalamic amines. Serum was separated after centrifugation at $4^{\circ} \mathrm{C}$ and $400 \mathrm{~g}$. The pituitary glands were weighed and homogenized individually in $1 \mathrm{ml} 0.154 \mathrm{M}-\mathrm{NaCl}$ which left no sediment. Serum and pituitary homogenates were stored at $-20^{\circ} \mathrm{C}$. The $\mathrm{LH}$ in both the gland and serum was assayed in triplicate according to the double-antibody radioimmunoassay described by Naftolin \& Corker (1971) and Kendle, Paterson \& Wilson (1978). The intra- and inter-assay coefficients of variance were 11 and $16 \%$ respectively and the standard was LER $C_{2} 1056$ (potency 1.73 times NIH-LH-S); the sensitivity was $2 \mathrm{ng}$. FSH was assayed in duplicate in a further group of mice of similar age (5-7 months, $N=14$ ) using an NIAMDD kit. The intra- and inter-assay coefficients of variance were 5 and $4 \%$ respectively and the standard was NIAMDD-FSH-RP1; the sensitivity was $20 \mathrm{ng}$.

\section{In-vitro release of $\mathrm{LH}$}

Groups of intact male or ovariectomized female (obese and wild-type, $\mathrm{N}=3-9,6-9$ months old) mice were left untreated or treated 5 weeks post-operatively with $0.1 \mathrm{ml}$ corn oil s.c. containing 0 , 1 , or $10 \mu \mathrm{g}$ oestradiol benzoate/100 g body weight. After a further $18 \mathrm{~h}$ the animals were decapitated at 10:00 h, the pituitary gland removed and its neural and intermediate lobes separated. The glandular lobe was weighed (whole or halved) and placed immediately in phosphate-buffered saline (pH 7.2) containing 1\% BSA and then incubated according to the method of Wilkinson, de Ziegler, Cassard \& Ruf (1977) with the following modifications. The glands were preincubated for a continuous period of $2 \mathrm{~h}, \mathrm{LH}-\mathrm{RH}$ was introduced at a concentration of $8.5 \times 10^{-10} \mathrm{M}$ and after 60 min the medium was removed for the assay of $\mathrm{LH}$.

\section{Reproductive tract weight}

Vaginal smears were taken by flushing with physiological saline and stained with aqueous methylene blue. Smears in which squamous and/or epithelial cells predominated were considered indicative of oestrus. Smears containing predominantly leucocytes were associated with dioestrus. The wet weights of ovaries, uteri, testes and ventral prostate glands were determined in the 5-6-month-old animals used to determine hypothalamic amine content.

\section{Statistics}

Mean \pm s.e.m. values for groups of obese and wild-type mice in each experiment were compared for significance using Student's $t$ test, when the variances were homogeneous; in cases where the variances were not homogeneous the Cochran approximation towards the Behrens-Fisher solution was applied to the $t$ value (Snedecor \& Cochran, 1976). 


\section{Results}

\section{Hypothalamic amines}

All values for obese mice were as great as, or greater than, those for wild-type mice. Concentrations of hypothalamic 5-hydroxytryptamine in obese mice were not significantly different from those of any wild-type group, but values of its chief metabolite, 5hydroxyindoleacetic acid, were significantly raised in male obese mice (Table 1). Mean values for noradrenaline were significantly higher in both sexes of obese mice when compared with wild-type male animals or females in dioestrus. Obese females showed similar concentrations of noradrenaline as did oestrous wild-type mice. Dopamine values were similar in obese and wild-type mice.

Table 1. Hypothalamic amines (5-hydroxyindoleacetic acid $=5$ HIAA; 5-hydroxytryptamine $=5 \mathrm{HT}$; noradrenaline $=\mathrm{NA}$; dopamine $=\mathrm{DA})$ in obese and wild-type mice at 5-6 months of age

\begin{tabular}{|c|c|c|c|c|c|c|c|}
\hline \multirow[b]{2}{*}{ Group } & \multirow{2}{*}{$\begin{array}{l}\text { No. of } \\
\text { mice }\end{array}$} & \multirow{2}{*}{$\begin{array}{l}\text { Body wt } \\
\text { (g) }\end{array}$} & \multirow{2}{*}{$\begin{array}{c}\text { Wt of } \\
\text { hypothalamus } \\
\text { (mg) }\end{array}$} & \multicolumn{4}{|c|}{ Amine conc. (ng/100 mg hypothalamus) } \\
\hline & & & & 5HIAA & $5 \mathrm{HT}$ & NA & DA \\
\hline $\begin{array}{l}\text { Obese } \delta \\
\text { Wild } \delta\end{array}$ & $\begin{array}{l}8 \\
6\end{array}$ & $\begin{array}{l}80 \cdot 3 \pm 4 \cdot 2 \\
42 \cdot 3 \pm 0 \cdot 6^{* * *}\end{array}$ & $\begin{array}{l}14.5 \pm 0.68 \\
13.8 \pm 0.65\end{array}$ & $\begin{array}{r}134 \pm 22 \\
52 \pm 8^{* *}\end{array}$ & $\begin{array}{l}360 \pm 30 \\
327 \pm 31\end{array}$ & $\begin{array}{l}265 \pm 20 \\
195 \pm 13^{*}\end{array}$ & $\begin{array}{l}168 \pm 22 \\
138 \pm 22\end{array}$ \\
\hline $\begin{array}{l}\text { Obese } q \\
\text { Wild } q \\
\text { (oestrous) }\end{array}$ & $\begin{array}{l}8 \\
8\end{array}$ & $\begin{array}{l}84 \cdot 8 \pm 2 \cdot 6 \\
32 \cdot 1 \pm 0.6^{* * *}\end{array}$ & $\left\{\begin{array}{l}14.2 \pm 0.71 \\
14.3 \pm 0.61\end{array}\right.$ & $\begin{array}{l}140 \pm 14 \\
119 \pm 13\end{array}$ & $\begin{array}{l}191 \pm 21 \\
248 \pm 21\end{array}$ & $\begin{array}{l}243 \pm 18 \\
226 \pm 18\end{array}$ & $\begin{array}{l}214 \pm 29 \\
259 \pm 17\end{array}$ \\
\hline $\begin{array}{l}\text { Wild } q \\
\quad \text { (dioestrous) }\end{array}$ & 8 & $31.4 \pm 0.9 * * *$ & & $112 \pm 12$ & $205 \pm 12$ & $173 \pm 14^{* *}$ & $204 \pm 24$ \\
\hline
\end{tabular}

Values are mean \pm s.e.m.

Values significantly different from that for corresponding obese mice, ${ }^{*} P<0.02,{ }^{* *} P<0.01,{ }^{* * *} P<0.001$.

\section{Hypothalamic $L H-R H$}

The concentration and content of hypothalamic $\mathrm{LH}-\mathrm{RH}$, measured by radioimmunoassay, were greater in 5-8-month-old male and female obese mice than in their wild-type controls (Table 2). This relationship was reversed for old obese male mice, but the value for wild-type male mice remained unchanged with age. The bioassay results for hypothalamic extracts from female obese and wild-type mice did not differ significantly.

Table 2. Hypothalamic content and concentration of LH-RH in obese and wild-type mice

\begin{tabular}{|c|c|c|c|c|c|c|}
\hline \multirow[b]{3}{*}{ Group } & \multirow{3}{*}{$\begin{array}{l}\text { No. of } \\
\text { mice }\end{array}$} & \multirow{3}{*}{$\begin{array}{c}\text { Age } \\
\text { (months) }\end{array}$} & \multirow[b]{3}{*}{ Body wt (g) } & \multicolumn{3}{|c|}{ LH-RH } \\
\hline & & & & \multicolumn{2}{|c|}{ RIA } & \multirow{2}{*}{$\frac{\text { Bioassay }}{\text { ng/hypothalamus }}$} \\
\hline & & & & $\mathrm{ng} / \mathrm{mg}$ & $\mathrm{ng} / \mathrm{hypothalamus}$ & \\
\hline $\begin{array}{l}\text { Obese } \sigma^{\pi} \\
\text { Wild } \sigma^{\pi}\end{array}$ & $\begin{array}{l}8 \\
7\end{array}$ & $5-6$ & $\begin{array}{l}82.7 \pm 5 \cdot 1 \\
43 \cdot 1 \pm 0.5^{* * *}\end{array}$ & $\begin{array}{l}252 \pm 14 \\
166 \pm 6^{* * * *}\end{array}$ & $\begin{array}{l}3961 \pm 290 \\
2883 \pm 169^{* *}\end{array}$ & - \\
\hline $\begin{array}{l}\text { Obese } \delta \\
\text { Wild } \delta\end{array}$ & $\begin{array}{l}7 \\
7\end{array}$ & 13 & $\begin{array}{l}79 \cdot 5 \pm 14 \cdot 7 \\
39 \cdot 8 \pm 1 \cdot 3^{* * *}\end{array}$ & $\begin{array}{l}104 \pm 6 \\
151 \pm 14^{* *}\end{array}$ & $\begin{array}{l}1415 \pm 75 \\
2462 \pm 383^{*}\end{array}$ & - \\
\hline $\begin{array}{l}\text { Obese } q \\
\text { Wild } q\end{array}$ & $\begin{array}{l}9 \\
9\end{array}$ & 8 & $\begin{array}{l}107 \cdot 1 \pm 7 \cdot 2 \\
34 \cdot 3 \pm 0 \cdot 6^{* * *}\end{array}$ & $\begin{aligned} 126 & \pm 11 \\
89 & \pm 6^{* * *}\end{aligned}$ & $\begin{array}{l}2764 \pm 275 \\
1805 \pm 107^{* *}\end{array}$ & $\begin{array}{l}667 \pm 138(5) \\
712 \pm 128(5)\end{array}$ \\
\hline
\end{tabular}

Values are mean \pm s.e.m.

Values significantly different from that for corresponding obese mice: ${ }^{*} P<0.02,{ }^{* *} P<0.01,{ }^{* * *} P<0.001$. 


\section{Pituitary and serum $\mathrm{LH}$ and FSH}

Pituitary glands of female obese mice weighed significantly less than those of wild-type mice (Table 3). Pituitary content of LH was significantly lower for female obese mice, although there was no difference in content in male obese mice or in concentration in either sex. LH serum concentration in obese and wild-type mice were also similar (Table 3). The pituitary concentration of FSH was significantly higher in obese male mice than in their controls. A significant change in concentration of pituitary FSH in wild-type mice was associated with stages of the oestrous cycle: obese female mice had significantly higher concentrations than wild-type animals at dioestrus but not when compared with those at oestrus. Serum FSH concentrations were significantly lower in obese mice of both sexes, compared with wild-type mice (Table 3).

Table 3. Pituitary and serum $\mathrm{LH}$ and FSH values in obese and wild-type mice at 5-7 months of age

\begin{tabular}{|c|c|c|c|c|c|}
\hline & \multirow[b]{2}{*}{ Obese male } & \multirow{2}{*}{$\begin{array}{l}\text { Wild-type } \\
\text { male }\end{array}$} & \multirow[b]{2}{*}{ Obese female } & \multicolumn{2}{|c|}{ Wild-type female } \\
\hline & & & & Oestrous & Dioestrous \\
\hline \multicolumn{6}{|l|}{ Pituitary } \\
\hline Weight (mg) & $2 \cdot 27 \underset{(8)}{ \pm 0} 0.14$ & $2.97 \pm \frac{(7)}{ \pm 0.20}$ & $2 \cdot 90 \pm 0.17$ & $c^{c} 4.42 \pm 0.26$ & ${ }^{c} 4.17 \underset{(8)}{ \pm 0.27}$ \\
\hline LH ( $\mu \mathrm{g} /$ gland) & $1.50 \pm \frac{0}{(8)} 0.14$ & $2.00 \pm 0.20$ & $0.58 \pm 0.05$ & ${ }^{c} 0.91 \pm 0.08$ & ${ }^{\circ} 0.87 \pm 0.05$ \\
\hline$(\mu \mathrm{g} / \mathrm{mg})$ & $0.76 \pm \underset{(8)}{ \pm 0.12}$ & $0.66 \pm 0.07$ & $0.20 \pm 0.02$ & $0.21 \pm 0.02$ & $0.21 \pm 0.01$ \\
\hline FSH ( $\mu \mathrm{g} /$ gland) & $32 \cdot 4 \div 3.3$ & $\begin{array}{c}25 \cdot 8 \pm 3 \cdot 2 \\
(11)\end{array}$ & $7 \cdot 5 \pm \frac{ \pm}{(9)} 1 \cdot 1$ & $\begin{array}{c}14.6 \pm 3.8 \\
(6)\end{array}$ & ${ }^{2} 4.4 \pm 0.2$ \\
\hline$(\mu \mathrm{g} / \mathrm{mg})$ & $14 \cdot 3 \pm 1 \cdot 4$ & $\begin{array}{c}8.7 \pm 1.1 \\
(11)\end{array}$ & $2.6 \pm 0.42$ & $\begin{array}{c}3.3 \pm 0.86 \\
(6)\end{array}$ & $d_{1.05} \pm 0.05$ \\
\hline \multicolumn{6}{|l|}{ Serum } \\
\hline $\mathrm{LH}(\mathrm{ng} / \mathrm{ml})$ & $1 \cdot 10 \pm \frac{0.22}{(8)}$ & $0.96 \pm \underset{(7)}{ \pm 0.23}$ & $0.83 \pm 0.14$ & $0.90 \pm 0.15$ & $0.88 \pm \underset{(8)}{0.09}$ \\
\hline $\mathrm{FSH}(\mu \mathrm{g} / \mathrm{ml})$ & $\begin{array}{c}1.32 \pm 0.08 \\
(14)\end{array}$ & ${ }^{b_{1}} 1.74 \pm 0.13$ & $\begin{array}{c}0.26 \pm 0.03 \\
(14)\end{array}$ & ${ }_{(14)} 1.28 \pm 0.36$ & $\begin{array}{c}c 0.52 \pm 0.07 \\
\text { (14) }\end{array}$ \\
\hline
\end{tabular}

Values are mean \pm s.e.m. for no. of samples in parentheses.

Values significantly different from that for obese mice, ${ }^{\mathrm{a}} P<0.05,{ }^{\mathrm{b}} P<0.02,{ }^{\mathrm{c}} P<0.01,{ }^{\mathrm{d}} P<0.001$.

Table 4. In-vitro release of LH from anterior pituitary glands of obese and wild-type mice in response to $8.5 \times 10^{-10} \mathrm{M}-\mathrm{LH}-\mathrm{RH}$

\begin{tabular}{|c|c|c|c|c|c|}
\hline Group & $\begin{array}{l}\text { No. of mice } \\
\text { and incubations }\end{array}$ & Treatment & $\begin{array}{l}\text { Body wt } \\
(\mathrm{g})\end{array}$ & $\begin{array}{c}\text { Wt }(\mathrm{mg}) \text { of } \\
\text { anterior pituitary } \\
\left(\delta^{\star}, \text { whole: } q, \text { halved }\right)\end{array}$ & $\begin{array}{c}\text { LH release } \\
\left(\mathrm{ng} / \mathrm{ml} \cdot \mathrm{mg}^{-1} \cdot \mathrm{h}^{-1}\right)\end{array}$ \\
\hline $\begin{array}{l}\text { Obese } \delta \\
\text { Wild } \delta\end{array}$ & $\begin{array}{l}9,9 \\
8,8\end{array}$ & - & $\begin{array}{l}98 \cdot 0 \pm 5 \cdot 8 \\
41 \cdot 3 \pm 2 \cdot 1^{* * *}\end{array}$ & $\begin{array}{l}1.90 \pm 0.10 \\
2 \cdot 60 \pm 0.12^{* *}\end{array}$ & $\begin{array}{c}58 \cdot 5 \pm 6.4 \\
69.3 \pm 6 \cdot 0\end{array}$ \\
\hline $\begin{array}{l}\text { Obese } \\
\text { Wild }\end{array}$ & $\begin{array}{l}8,8 \\
8,8\end{array}$ & $\begin{array}{l}\text { Ovariectomy } \\
\text { Ovariectomy }\end{array}$ & $\begin{array}{l}99.6 \pm 4.9 \\
37.3 \pm 1.2^{* * *}\end{array}$ & $\begin{array}{l}1.09 \pm 0.06 \\
1.34 \pm 0.10^{*}\end{array}$ & $\begin{array}{l}179 \cdot 2 \pm 29.4 \\
114 \cdot 8 \pm 12 \cdot 1^{* \dagger}\end{array}$ \\
\hline Obese ? & 3,6 & $\begin{array}{l}\text { Ovariectomy }+1 \mu \mathrm{g} \\
\text { oestradiol benzoate } / 100 \mathrm{~g}\end{array}$ & $100 \cdot 7$ & $1.08 \pm 0.05$ & $142.3 \pm 11.0$ \\
\hline Wild o & 3,6 & $\begin{array}{l}\text { Ovariectomy }+1 \mu \mathrm{g} \\
\text { oestradiol benzoate } / 100 \mathrm{~g}\end{array}$ & $38 \cdot 3$ & $1.50 \pm 0.09^{* *}$ & $101 \cdot 9 \pm 4 \cdot 2^{*}$ \\
\hline Obese $q$ & 3,6 & $\begin{array}{l}\text { Ovariectomy }+10 \mu \mathrm{g} \\
\quad \text { oestradiol benzoate } / 100 \mathrm{~g}\end{array}$ & $101 \cdot 2$ & $1 \cdot 23 \pm 0.12$ & $165 \cdot 7 \pm 18 \cdot 6$ \\
\hline Wild & 3,6 & $\begin{array}{l}\text { Ovariectomy }+10 \mu \mathrm{g} \\
\text { oestradiol benzoate } / 100 \mathrm{~g}\end{array}$ & 37.8 & $1.51 \pm 0.14$ & $75 \cdot 8 \pm 6 \cdot 3^{* * \dagger}$ \\
\hline
\end{tabular}




\section{In-vitro release of $L H$}

The anterior pituitary, as well as the whole gland (see Table 3), weighed less in obese than in wild-type mice (Table 4). The difference was significant in male and in ovariectomized female mice, the latter before, as well as after, treatment with oestradiol benzoate. LH release in response to LH-RH from the gland of male obese mice was not significantly different from that from wild-type controls, although LH release from the anterior pituitaries of ovariectomized obese females was significantly greater than that from wild-type controls. Pretreatment with 1 or $10 \mu \mathrm{g}$ oestradiol benzoate $/ 100 \mathrm{~g}$ did not alter the sensitivity in obese mice but $10 \mu \mathrm{g}$ oestradiol benzoate significantly reduced the sensitivity of the pituitary glands of wild-type mice.

\section{Reproductive tract}

The ovaries and uteri of wild-type mice at oestrus $(19.9 \pm 1.5,107.0 \pm 12.4 \mathrm{mg})$ and dioestrus $(16.7 \pm 0.8,70.1 \pm 4.1 \mathrm{mg})$ were significantly heavier $(P<0.001)$ than those of the obese animals $(11.4 \pm 0.6,28.2 \pm 2.3 \mathrm{mg})$. The testes and ventral prostate were also heavier in the wild-type $(311 \pm 7,29.0 \pm 1.7 \mathrm{mg})$ than the obese $(247 \pm 25,19.6 \pm 4.6 \mathrm{mg})$ mice, the difference being significant for the testes $(P<0.05)$.

\section{Discussion}

The hypogonadism of the obese mouse has been imputed to low levels of circulating gonadotrophins and we confirm the reduced FSH with normal LH levels reported in male mice by Swerdloff et al. (1976). The present study has been extended to include female obese mice in which tonic LH levels are also similar to those of control animals and FSH levels reduced significantly. Although preovulatory surges of LH and FSH were demonstrated for wild-type animals (Murr, Geschwind \& Bradford, 1973), in this study it is unlikely that gonadotrophin surges occur in obese mice because they are totally anovulatory (Hummel, 1957) with the characteristic vaginal smear consisting of leucocytes only. In keeping with previous reports, gonadal accessory organ weights were reduced in the obese mice compared with wild-type litter mates.

Pituitary weights in both sexes were consistently lower in the obese mouse. With the lower pituitary weight there was a reduction in LH content in the female obese mouse, but concentration was not reduced in either sex. In contrast FSH pituitary content was similar and its concentration significantly increased in obese mice compared with wild-type male and dioestrous female mice; values in the obese female and wild-type oestrous female groups were similar. Low pituitary LH with high FSH content has been reported previously for obese male mice (Batt, Bray and Swerdloff, 1973; Swerdloff et al., 1976). The high concentrations of pituitary FSH, together with the low serum concentrations, suggest impaired FSH release in both sexes of the obese mouse.

Pituitary gland sensitivity towards LH-RH in vitro (LH release) was normal in the male obese mouse and significantly greater in the female obese than in the wild-type mouse (ovariectomized animals). Oestrogen treatment at a dose of $10 \mu \mathrm{g} / 100 \mathrm{~g}$ body weight appeared to desensitize the pituitary glands from the wild-type mice rather than have a sensitizing effect, as in the rat (Wilkinson et al., 1977). A species difference may be indicated. Oestrogen had no effect on the sensitivity of the pituitary glands of the obese mouse. Swerdloff et al. (1978) showed that 7-week-old male obese mice have a lower response (LH release) to acute LH-RH administration in vivo than do wild-type controls, although there was a greater response to chronic treatment. Swerdloff et al. (1978) also demonstrated that the proportion of pituitary LH and FSH released was greater for LH and less for FSH in the obese than in the wild-type mouse. 
It might be of interest to compare $\mathrm{LH}$ and FSH released in vitro from pituitary glands of obese mice to determine whether a selective release of gonadotrophins occurs, resulting in an imbalance of liberated FSH and LH. However, Swerdloff et al. (1976), measuring the in-vivo rise in serum FSH and LH following castration of wild-type and obese male mice (without an exogenous LH-RH stimulus), found that the slope in wild-type mice paralleled that in obese mice for both gonadotrophins.

The content and concentration of LH-RH in hypothalami of young adults of both sexes were significantly higher in obese animals, as measured by radioimmunoassay, but measurement by bioassay gave similar values for obese and wild-type females. The bioassay was not physiological in that mouse extract was used to cause the release of LH from rat pituitary cells, but the results indicate that the LH-RH in the obese mouse does have biological activity. In older male mice ( 13 months of age) the LH-RH concentration remained constant for wild-type but became significantly reduced in obese animals, confirming the results of Nemeroff et al. (1978) working with obese animals $>8$ months of age.

The secretion of releasing hormones may be controlled by hypothalamic amines (Wilson, 1979) and some of these have been measured in the present study. Hypothalamic noradrenaline concentration was significantly higher in the obese than in the wild-type male and dioestrous wild-type female animals. This confirms the findings of Lorden, Oltmans \& Margules (1975) and Lorden \& Oltmans (1977). The present results also show that obese female mice have concentrations of noradrenaline similar to those in the wild-type group at oestrus and since pituitary FSH concentrations vary in parallel with those of hypothalamic noradrenaline they may be functionally associated. It is possible that hypothalamic noradrenaline is reduced in old age in parallel with the reduction in $\mathrm{LH}-\mathrm{RH}$ concentration because no difference in noradrenaline concentration was found for old obese and wild-type mice by Nemeroff et al. (1978). It is possible LH-RH and noradrenaline release, but not synthesis, is inhibited by some means in the younger animal, and that eventually the reduced release is matched by reduced synthesis.

Dopamine and 5-hydroxytryptamine concentrations were not significantly different in the two groups, the former result confirming that of Feldman, Blalock \& Zern (1979). Concentrations of 5-hydroxyindoleacetic acid were higher in male obese animals, indicating an increased 5-hydroxytryptamine release (Hery, Rouer \& Glowinski, 1972). Garthwaite, Kalkhoff, Guansing, Hagen \& Menahan (1979) have shown a higher 5-hydroxytryptamine concentration for the whole brain of obese male mice, due probably to raised levels of plasma tryptophan (the rate-limiting factor in brain 5-hydroxytryptamine synthesis).

We suggest that an impaired release of FSH in the obese mouse is caused by an inadequacy in the mechanism of release of LH-RH. This is probably associated with the animal's extreme sensitivity towards the negative feedback effect of gonadal steroids (Swerdloff et al., 1976). The sensitivity of the feedback might be the cause of the paradoxical combination of low levels of circulating gonadal steroids with low gonadotrophins. Of the hypothalamic neurotransmitters, noradrenaline has been particularly associated with LH-RH release (Wilson, 1979) but it would be premature to relate its raised level to the hypogonadism in the obese mouse. Our in-vitro studies on LH release do not confirm an intrinsic incapacity of the pituitary gland and the in-vivo results of Swerdloff et al. (1978) may be interpreted as showing normal or near normal changes in pituitary and serum gonadotrophins. In-vitro release of $\mathrm{FSH}$, alone or relative to that of $\mathrm{LH}$, has not been determined for the obese mouse.

Margules, Moisset, Lewis, Shibuya \& Pert (1978) have reported high levels of pituitary and plasma beta-endorphins for the obese mouse. Opiate peptides suppress the release of LH-RH and enhance pituitary sensitivity to the hormone (Evans \& Groom, 1980). These findings together with those of the present study suggest that beta-endorphins have a possible role in causing the hypogonadism of the obese mouse. 
We thank Dr C. H. Mortimer for providing antiserum to LH-RH; NIAMDD, Bethesda, U.S.A., for LH and FSH assay kits; M. J. Andrews for excellent technical work; and J. Wise for advice on the statistical methods. The Nuffield Foundation supported the in-vitro studies on $\mathbf{L H}$ release.

\section{References}

Batt, R.A.L. (1972) The response of the reproductive system in the female mutant mouse, obese (genotype $\mathrm{ob} / \mathrm{ob}$ ) to gonadotrophin-releasing hormones. $J$. Reprod. Fert. 31, 496-497.

Batt, R.A.L. (1974) Studies on the pathogenesis of the mutant mouse 'Obese'. Ph.D. thesis, University of Reading.

Batt, R.A.L., Bray, G.A. \& Swerdlofi, R.S. (1973) Evidence of inadequate release of LH-RH in the obese hyperglycaemic mouse. Clin. Res. 21, 249.

Bray, G.A. \& York, D.A. (1979) Hypothalamic and genetic obesity in experimental animals: an autonomic and endocrine hypothesis. Physiol. Rev. 59, $719-809$.

Curzon, G. \& Green, A.R. (1970) A rapid method for the determination of 5-hydroxytryptamine and 5hydroxyindoleacetic acid in small regions of the rat brain. Br. J. Pharmac. Chemother. 39, 653-655.

Drasher, M.L., Dickie, M.M. \& Lane, P.W. (1955) Physiological differences in uteri of obese stock mice. J. Hered. 46, 209-212.

Evans, G. \& Groom, G.V. (1980) A role for the opiate receptor pathway in the hypothalamic control of anterior pituitary hormone release J. Endocr. 87, 39P, Abstr.

Feldman, J.M., Blalock, J.A. \& Zern, R.T. (1979) Elevated hypothalamic norepinephrine content in mice with hereditary obese hyperglycaemic syndrome. Horm. Res. 11, 170-178.

Garthwaite, T.L., Kalkhoff, R.K., Guansing, A.R., Hagen, T.C. \& Menahan, L.A. (1979) Plasma free tryptophan, brain serotonin and an endocrine profile of the genetically obese hyperglycaemic mouse at 4-5 months of age. Endocrinology 105, 1178-1182.

Gillies, G. \& Lowry, P.J. (1978) Perfused rat isolated anterior pituitary cell column as bioassay for factor(s) controlling release of adrenocorticotrophin: validation of a technique. Endocrinology 103, 521527.

Glowinski, J. \& Iversen, L. (1966) Regional studies of catecholamines in the rat brain. Biochem. Pharmacol. 15, 977-987.

Hery, F., Rouer, E. \& Glowinski, J. (1972) Daily variations of serotonin metabolism in the rat brain. Brain Res. 43, 445-465.

Hummel, K.P. (1957) Transplantation of ovaries of the obese mouse. Anat. Rec. 128, 569.

Jones, N. \& Harrison, G.A. (1958) Genetically determined obesity and sterility in the mouse. Stud. Fert. 9, 51-61.

Kendle, K.E., Paterson, J.R. \& Wilson, C.A. (1978) Effects of RMI 12936, a synthetic antiprogestational steroid, on the oestrous cycle and ovulation in the rat. J. Reprod. Fert. 53, 363-368.
Lane, P.W. (1959) The pituitary-gonad response of genetically obese mice in parabiosis with thin and obese siblings. Endocrinology 65, 863-868.

Lorden, J.F. \& Oltmans, G.A. (1977) Hypothalamic and pituitary catecholamine levels in genetically obese mice (ob/ob). Brain Res. 131, 162-166.

Lorden, J.F., Oltmans, G.A. \& Margules, D.L. (1975) Central catecholamine levels in genetically obese mice (obob \& dbdb). Brain Res. 96, 390-394.

Margules, D.L., Moisset, B., Lewis, M.J., Shibuya, H. \& Pert, C.V. (1978) $\beta$-endorphin is associated with overeating in genetically obese mice (ob/ob) and rats (fa/fa). Science, N.Y. 202, 988-991.

Mortimer, C.H., MeNeilly, A.S., Rees, L.H., Lowry, P.J., Gilmore, D. \& Dobbie, H.G. (1976) Radioimmunoassay and chromatographic similarity of circulating endogenous gonadotrophin releasing hormone and hypothalamic extracts in man. $J$. clin. Endocr. Metab. 43, 882-888.

Murr, S.M., Geschwind, I.I. \& Bradford, G.E. (1973) Plasma LH and FSH during different oestrous cycle conditions in mice. J. Reprod. Fert. 32, 221-230.

Naftolin, F. \& Corker, C.S. (1971) An ultramicromethod for the measurement of luteinizing hormone by radioimmunoassay. In Radioimmunoassay Methods, pp. 641-645. Eds K. E. Kirkham \& W. M. Hunter. Churchill Livingstone, Edinburgh.

Nemeroff, C.B., Bissette, G. \& Kizer, J.S. (1978) Reduced hypothalamic content of immunoreactive LH-RH-like activity in genetically obese (ob/ob) mice. Brain Res. 146, 385-387.

Runner, M.N. (1952) Study of the ovarian and pituitary function of the obese mouse. In Conference on the Obese Mouse, pp. 6-8. Roscoe B. Jackson Memorial Laboratory, Bar Harbor, Maine, U.S.A.

Shellenberger, M.K. \& Gordon, J.H. (1971) A rapid simplified procedure for simultaneous assay of norepinephrine, dopamine and 5-hydroxytryptamine. Analyt. Biochem. 39, 356-372.

Snedecor, G.W. \& Cochran, W.G. (1976) In Statistical Methods, 6th edn, p. 115. Iowa State University Press, Ames.

Swerdloff, R.S., Batt, R.A. \& Bray, G.A. (1976) Reproductive hormonal function in the genetically obese (ob/ob) mouse. Endocrinology 98, 1359-1364.

Swerdloff, R.S., Peterson, M., Vera, A., Batt, R.A.L., Heber, D. \& Bray, G.A. (1978) The hypothalamicpituitary axis in genetically obese (ob/ob) mice: response to luteinizing hormone-releasing hormone. Endocrinology 103, 542-547.

Weisch, A.M. \& Welsch, B.L. (1969) A solvent extraction method for simultaneous determination of norepinephrine, dopamine, serotonin and 5-hydroxy- 
indoleacetic acid in a single mouse brain. Analyt. Biochem. 30, 161-179.

Wilkinson, M., de Ziegler, D., Cassard, D. \& Ruf, K.B. (1977) In vitro studies of the effects of oestrogen pretreatment on the sensitivity of the immature female rat pituitary gland to stimulation with gonadotrophin releasing hormone. J. Endocr. 74, 11-21.

Wilson, C.A.J. (1979) Hypothalamic neurotransmitters and gonadotrophin release. In Oxford Reviews in Reproduction, pp. 383-473. Ed. C. A. Finn. Oxford Medical Publications.
Yeo, T.A., Mortimer, C.H., Thorner, M.O., Lowry, P.M., Rees, L.H. \& Besser, G.M. (1977) A bioassay for the gonadotrophin-releasing hormone using perfused rat anterior pituitary cell columns. J. Endocr. 73, 36P, Abstr.

York, D.A., Bray, G.A. \& Yukimura, Y. (1978) An enzymatic defect in the obese (ob/ob) mouse: loss of thyroid-induced sodium and potassium-dependent adenosine triphosphatase. Proc. natn. Acad. Sci., U.S.A. 75, 477-481.

Received 22 April 1981 